Krzysztof Szczygielski

\title{
Terminologia odnosząca się do konkubinatu w polskim ustawodawstwie synodalnym XII-XVIII w.
}

Keywords: Concubinage, Synodal legislation

\begin{abstract}
Summary
The question of concubinage was very often mentioned in the sources of Polish synodal legislation in $12^{\text {th }}-18^{\text {th }}$ centuries. This extramarital union between a man and a woman was defined by the Latin term concubinatus. The more descriptive expressions used to explain this relation are as follows: peccandi libidinum, scelerata consuetudo or damnaticius status. The most extended terminology refers to the most relevant matter for the Catholic Church, namely to break with the sinful intercourse by the Christ's faithful. The analysis of synodal decrees indicates that provided terminology expressed moral and legal qualification of living in concubinage. It was characterized by the pejorative meaning. Undoubtedly, it reflected the negative attitude of the Church towards these extramarital relations and people remaining in them. Provided terms applied mostly to clerics living in statu concubinatu. It shows how much attention the ecclesiastical authorities pay to clerical discipline. However, the fragments regarding the fight with concubinage of Christ's faithful are less common. Particular legislators broadly used the terminology provided by the universal Canon law.
\end{abstract}

W rozwoju ustawodawstwa synodalnego Kościoła katolickiego w Polsce wyróżnić można zasadniczo dwa okresy. Ramy czasowe pierwszego z nich wyznaczają daty średniowiecznych synodów z XII-XIII w. i odbycie ostatnich zgromadzeń synodalnych na ziemiach polskich przed rozbiorami dokonanymi w drugiej połowie XVIII stulecia. W czasie pozostawania naszego kraju pod protektoratem państw zaborczych nie było sprzyjających warunków do pro- 
wadzenia działalności synodalnej, co spowodowało niemal całkowity jej zanik ${ }^{1}$. Stąd o początku drugiego okresu w historii prawodawstwa synodalnego można mówić dopiero w chwili odzyskania przez państwo polskie niepodległości, która zbiegła się praktycznie z promulgacją przez papieża Benedykta XV (1914-1922) bullą Providentissima Mater Ecclesia z 27 maja 1917 r. Kodeksu Prawa Kanonicznego Kościoła łacińskiego, z mocą obowiązującą od 19 maja $1918 \mathrm{r}^{2} \mathrm{Ni}$ niejsze opracowanie ma na celu przedstawienie terminologii stosowanej wobec zjawiska konkubinatu wiernych świeckich, jak również osób stanu duchownego w pierwszym z przedstawionych okresów.

We wspomnianym okresie zaobserwować można aktywną pracę na polu prawodawczym. Widocznym świadectwem tego zaangażowania było zwołanie licznych synodów prowincjonalnych ${ }^{3}$, odbywanych pod przewodnictwem legatów papieskich bądź metropolitów i diecezjalnych ${ }^{4}$, którym przewodniczyli biskupi. W ich aktach znajduje się wiele regulacji prawnych poruszających problematykę konkubinatu. Analiza wybranych statutów synodalnych zmierza do udzielenia odpowiedzi na szereg pytań, a w szczególności: Czy stosowana terminologia wyrażała obok prawnej także i moralną ocenę pożycia w konkubinacie? Czy poszczególni prawodawcy zajmowali w kwestii trwania w tym związku jednakowe stanowisko wobec wiernych świeckich i duchownych? Czy w badanym okresie dostrzec można ewolucję stosunku Kościoła w Polsce do tego rodzaju pozamałżeńskich relacji?

\section{Terminy podstawowe}

Kluczowym terminem odnoszącym się do określenia stałego, nieślubnego pożycia mężczyzny z kobietą, jakim posługiwało się polskie przedrozbiorowe prawo synodalne, był łaciński termin concubinatus, który Kościół przejął z ter-

1 W. Wójcik, Ze studiów nad synodami polskimi, Lublin 1982, s. 193-194. Wyjątkiem pod tym względem był obszar zaboru austriackiego, gdzie biskup diecezji przemyskiej Józef Sebastian Pelczar przeprowadził trzy zgromadzenia synodalne, kolejno w latach 1902 (zob. Acta et Statuta Synodi Dioecesanae Premisliensis quam A.D. 1902 diebus 19, 20, 21, 22 Mensis Augusti habuit Josephus Sebastianus Pelczar Episcopus Premisliensis Latinorum, Premisliae 1903); 1908 (zob. Akta i Statuta Kongregacyi Synodalnej czyli Synodu dyecezalnego dwudziestego odbytego w dniach 25, 26 i 27 sierpnia 1908 r. w Przemyślu pod przewodnictwem Józefa Sebastyana Pelczara biskupa przemyskiego ob. łac., Przemyśl 1908) i 1914 (zob. Akta Kongregacyi Synodalnej czyli Synodu dyecezalnego dwudziestego pierwszego odbytego w dniach 7, 8 i 9 lipca 1914 r. w Chyrowie pod przewodnictwem Józefa Sebastyana Pelczara biskupa przemyskiego ob. łac., Przemyśl 1916). Zob. także J. R. Bar, Synody biskupa przemyskiego Józefa Sebastiana Pelczara, „Ateneum Kapłańskie” 1950, nr 52, s. 198-210; idem, Działalność ustawodawcza biskupa przemyskiego J. S. Pelczara (1900-1924), „Prawo Kanoniczne” 1976, nr 3-4, s. 81-111.

2 Zob. „Acta Apostolicae Sedis” 1917, nr 9, pars II.

3 Szerzej na temat synodów prowincjonalnych zob. np. T. Gromnicki, Synody prowincyonalne oraz czynności niektórych funkcyonaryuszów apostolskich w Polsce do r. 1357, Kraków 1885; M. Morawski, Synod prowincjonalny prowincji gnieźnieńskiej w dawnej Polsce, Włocławek 1935; P. Kałwa, Rys historyczny prowincjonalnego ustawodawstwa synodalnego w Polsce przedrozbiorowej, [w:] Ksiega pamiatkowa ku czci Jego Ekscelencji X. Biskupa Mariana Leona Fulmana, cz. 1, Lublin 1939, s. 126-155; I. Subera, Historia źródet i nauki prawa kanonicznego, Warszawa 1977, s. 125-141.

${ }^{4}$ Szerzej na ten temat zob. np. M. Morawski, Synod diecezjalny w dawnej Polsce, Włocławek 1937. 
minologii prawa rzymskiego. Jego obecność odnotowuje się praktycznie we wszystkich źródłach badanego okresu ${ }^{5}$.

Etymologicznie concubinatus wywodzi się od concubina ${ }^{6}$, który to termin powstał w wyniku połączenia przedrostka cum (razem) i czasownika cubare (leżeć). Niektórzy jako źródło jego pochodzenia podają concubare, od złączenia con i cubare lub niekiedy concumbere, będące połączeniem con i cumbere ${ }^{7}$. Zaznaczyć jednak trzeba, iż wszystkie wymienione tutaj czasowniki są ze sobą zbieżne znaczeniowo i w sensie właściwym wiążą się z takimi czynności, jak leżenie z kimś, spanie razem ${ }^{8}$, obcowanie cielesne, spółkowanie ${ }^{9}$ czy też utrzymywanie stosunków płciowych ${ }^{10}$. W nawiązaniu do terminu określającego pozamałżeńskie stosunki partnerów, kobietę nazywano konkubiną (concubina) ${ }^{11}$, mężczyznę natomiast konkubinariuszem ${ }^{12}$ (concubinarius) ${ }^{13}$.

\section{Wyrażenia zamiennie stosowane $\mathrm{z}$ terminami podstawowymi}

Analizując terminologię, jaką posługiwano się przy określaniu trwałego nieślubnego związku między dwoma osobami odmiennej płci, podkreślić należy,

5 Tak np. Synodus Budensis anni 1279 Philippus Firmanus Episcopus Legatus, [w:] R. Hube, Antiquissimae Constitutiones Synodales provinciae Gneznensis (dalej: Antiquissimae), Petropoli 1856, s. 80; Kodyfikacja płocka biskupa Jakuba z 1398-1423 r., [w:] J. Sawicki, Concilia Poloniae (dalej: CP), t. 6: Synody diecezji płockiej $i$ ich statuty, Warszawa 1952, s. 232; Statuta Thomae Strzępiński Episcopi Cracoviensis Ann. MCCCCLIX, [w:]Starodawne Prawa Polskiego Pomniki, ed. U. Heyzmann (dalej: SPPP), t. 4, Kraków 1875, s. 112; Acta dioecesanae synodi Anno Domini MDLXXX, [w:] J. Sawicki, CP, t. 10: Synody diecezji wrocławskiej i ich statuty, Wrocław - Warszawa - Kraków 1963, s. 572.

6 Thesaurus Linguae Latinae, t. 4, Lipsiae 1906-1909, s.v. concubina, concubinatus, s. 98-99; Słownik łacińsko-polski, red. M. Plezia, t. 1, Warszawa 1998, s.v. concubina, concubinatus, s. 657.

7 J. Plassard, Le concubinat romain sous le Haut Empire, Toulouse 1921, s. 15; A. Walde, J. B. Hofmann, Lateinisches etymologisches Wörterbuch, t. 1, Heidelberg 1938, s.v. cubo, s. 298; A. Ernout, A. Meillet, Dictionnaire étymologique de la langue latine. Histoire des mots, Paris 1959, s.v. cubo, s. 153-154; Oxford Latin Dictionary, t. 2, Oxford 1969, s.v. concubina, concubo, concumbo, s. 391-392.

8 F. Bobrowski, Słownik łacińsko-polski, t. 1, Wilno 1841, s.v. concubo, s. 434; A. Jougan, Słownik kościelny łacińsko-polski, Warszawa 1992, s.v. concubo, s. 135; J. Sondel, Słownik łacińsko-polski dla prawników i historyków, Kraków 1997, s.v. concubo, s. 192.

9 F. Bobrowski, op. cit., t. 1, s.v. concumbo, s. 434; A. Jougan, op. cit., s.v. concumbo, s. 135; J. Sondel, op. cit., s.v. concumbo, s. 192; M. Plezia, op. cit., t. 1, s.v. concumbo, s. 658.

10 J. Sondel, op. cit., s.v. cubo, s. 236; M. Plezia, op. cit., t. 1, s.v. cubo, s. 801.

11 Zob. np. Synodus Siradiensis anni 1233 Fulco Archiepiscopus Gneznensis, [w:] Antiquissimae, s. 2; Constitutiones synodales Thomae episcopi Wratislaviensis anno 1279 promulgatae, CP, t. 10, s. 330; Statuty biskupa Jana z Książąt Litewskich z 1528 r., [w:] J. Sawicki, CP, t. 2: Synody diecezji wileńskiej i ich statuty, Warszawa 1948, s. 120; Acta Synodi Dioecesanae Luceoriensis per Bernardum Maciejowski... Anno Domini MDLXXXIX celebratae, ed. Z. Chodyński, Varsaviae 1875, s. 19; Statuta synodi A. 1641 celebratae ad Gregorium Zamoyski Episcopum Chelmensem, [w:] J. Sawicki, CP, t. 9: Synody diecezji chełmskiej obrządku łacińskiego z XVI-XVIII wieku i ich statuty, Wrocław 1957, s. 95.

12 Termin ten występuje wyłącznie w źródłach i literaturze prawa kanonicznego. Czynione przeze mnie próby odnalezienia go w kilku słownikach języka polskiego nie przyniosły rezultatu. Powszechnie przyjętym i stosowanym terminem na określenie mężczyzny pozostającego z kobietą w trwałym nieślubnym związku jest konkubent bądź też dużo rzadziej spotykany konkubin, zob. Praktyczny słownik współczesnej polszczyzny, red. H. Zgółkowa, t. 17, Poznań 1998, s. 164.

13 Statuta Joannis IV Grot Episcopi Cracoviensis Ann. MCCCXXXI, SPPP, t. 4, s. 38; Statuta Synodalia Nicolai Kurowski Episcopi Anno 1402, [w:] Z. Chodyński, Statuta Synodalia dioecesis Wladislaviensis et Pomeraniae (dalej: Statuta), Varsaviae 1890, s. 3. 
iż obok właściwego i technicznego terminu concubinatus, kanoniczne normy prawne zawierały także wiele różnorodnych zwrotów oraz wyrażeń opisowych traktujących o tej formie faktycznego pożycia. Do wyrażeń, jakie pojawiały się w omawianym kontekście zaliczyć trzeba następujące: scelerata consuetudo ${ }^{14}$ (przeklęty nawyk), peccandi libidinum ${ }^{15}$ (grzeszna żądza), peccandi propositum ${ }^{16}$ (grzeszny zamiar, sposób życia), prava consuetudo ${ }^{17}$ (nikczemne przyzwyczajenie), turpe commercium ${ }^{18}$ (szpetny związek), damnaticius status ${ }^{19}$ (stan godny potępienia), confusio et damnum ${ }^{20}$ (hańba i ujma na czci) oraz scandalum ${ }^{21}$ (zgorszenie) i malum ${ }^{22}$ (zło).

W stosunku do kobiet pozostających w konkubinacie, obok podstawowego terminu concubina, używano również alternatywnych określeń, na przykład takich jak mulieres concubinariae ${ }^{23}$. Wspomnieć jednak trzeba, iż szczególnie w przepisach regulujących kwestie wspólnego zamieszkiwania osób stanu duchownego z niewiastami nierzadko pojawiały się także inne zwroty i terminy. Do takich należał niewątpliwie zwrot femina suspecta ${ }^{24}$, stosowany wobec kobiet wzbudzających podejrzenia co do ich dobrej sławy ${ }^{25}$. Innymi, jakie zawierają źródła, były: focaria ${ }^{26}$ (kobieta pozostająca w służbie domowej u duchownego, kucharka), meretrix ${ }^{27}$ (nierządnica, nałożnica) - termin o ewidentnie nega-

14 Statuty synodalne wieluńsko-kaliskie Mikołaja Trąby z 1420 r. z materiałów przysposobionych przez B. Ulanowskiego uzupełnili i wydali J. Fijałek i A. Vetulani, Kraków 1915-1920-1951, s. 48.

${ }^{15}$ Statuty synodalne wieluńsko-kaliskie Mikołaja Traby..., s. 48.

${ }^{16}$ Statuta synodi A. 1415 celebratae, [w:] J. Sawicki, CP, t. 8: Synody diecezji przemyskiej obrządku łacińskiego i ich statuty, Wrocław 1955, s. 137.

${ }_{17}$ Constitutiones et decreta Synodi Dioecesanae Plocensis sub... Andrea Stanislao Kostka in Załuskie Załuski... Episcopo Plocensi Pultoviae Anno Dominii MDCCXXXIII celebratae, Varsaviae 1735, s. 22.

${ }^{18}$ Ibidem, s. 22.

${ }^{19}$ Acta dioecesanae synodi Anno Domini MDLXXX, CP, t. 10, s. 572.

${ }^{20}$ Synodus Wratislaviensis a. 1248 Jacobus Archidiaconus Leodiensis Legatus, [w:] Antiquissimae, s. 17.

${ }^{21}$ Statuta Joannis IV Grot Episcopi..., SPPP, t. 4, s. 38.

${ }^{22}$ Acta dioecesanae synodi Anno Domini MDLXXX, CP, t. 10, s. 572; Synodus Varmiensis sub Simone Rudnicki a. 1610, [w:] Z. Chodyński, E. Likowski, Decretales summorum pontificum pro Regno Poloniae et constitutiones synodorum provincialium et dioecesanarum Regni eiusdem ad summam collectae (dalej: Decretales), t. 3, Posnaniae 1883, s. 165.

${ }^{23}$ Statuty biskupa Jana z Książą Litewskich z 1528 r., CP, t. 2, s. 125; Rozporzadzenie synodalne biskupa Piotra Dunin-Wolskiego z 1589 r., CP, t. 6, s. 288.

${ }^{24}$ Synodus Unieioviensis a. 1326, [w:] Antiquissimae, s. 185.

${ }^{25}$ Statuty synodalne biskupa Tomasza Strzępińskiego z 1459 r., w których zamieszczono w całości konstytucję ogłoszoną na XX sesji soboru bazylejskiego z dnia 22 stycznia 1435 r. stanowiły, że notorycznym konkubentem jest ten, który: mulierem de incontinentia suspectam et infamatam tenet (utrzymuje niewiastę podejrzaną o brak umiarkowania i zniesławioną), SPPP, t. 4, s. 112.

${ }^{26}$ Constitutiones domini Wenceslai episcopi Wratislaviensis, CP, t. 10, s. 385; Statuta Synodalia domini Petri episcopi Wratislaviensis, CP, t. 10, s. 471.

${ }^{27}$ Tak Statuta Synodalia Nicolai Kurowski Episcopi Anno 1402, [w:] Statuta, s. 3; Statuta Synodalia Andreae episcopi Posnaniensis saeculo XV confecta, [w:] ed. U. Heyzmann, SPPP, t. 5: Supplementum, Kraków 1877, s. XIV; Uchwały synodu diecezjalnego gnieźnieńskiego z 1512 r., [w:] B. Ulanowski, Materyjały do Historyi ustawodawstwa synodalnego $w$ Polsce $w$ w. XVI, „Archiwum Komisji Prawniczej Akademii Umiejętności”, t. 1, Kraków 1895, s. 355; Synodus Dioecesana Wladislaviae die 21 Sept. 1516 
tywnym zabarwieniu, pojawiający się zwykle w stwierdzeniu: sed si meretricia facie indutus ei adhaerere incorrigibiliter non desierit, opisującym sytuację, w której mężczyzna trwa bez poprawy w swym uporze, nie oddalając partner$\mathrm{ki}^{28}$. Sporadycznie natomiast korzystano w stosunku do kobiet utrzymujących takie grzeszne relacje z terminów: scortum $^{29}$ (ladacznica - dosłownie: skóra), muliercula ${ }^{30}$ (kobietka, nierządnica) i fornicaria ${ }^{31}$ (rozpustnica).

Analizowane teksty źródłowe rzadko wzmiankowały o potomstwie zrodzonym z konkubinatu. $Z$ reguły nie stosowano wobec niego pejoratywnych określeń, lecz rozgraniczano wykroczenie rodziców i w sposób opisowy przekazywano informacje o pochodzeniu z takiego związku. Jako przykłady wspomnianej praktyki posłużyć mogą fragmenty synodów łęczyckiego Jakuba Świnki z 1285 r. ${ }^{32}$ czy krakowskiego Tomasza Strzępińskiego z 1459 r. ${ }^{33}$ Zdarzały się jednak i takie określenia jak filii ex fornicatione geniti (dzieci spłodzone w rozpuście), zamieszczone w kodyfikacji wieluńsko-kaliskiej Mikołaja Trąby z $1420 \mathrm{r}^{34}$

\section{Terminologia określająca istotę konkubinatu}

W ustawodawstwie synodalnym omawianego okresu starano się przede wszystkim wyraźnie odróżnić konkubinat, charakteryzujący się pewną ciągłością utrzymywanych przez strony stosunków, od sporadycznych aktów seksualnych. O takim rozumieniu jego natury świadczyły w szczególności wyrażenia:

a. celebrata Matthias Drevicius..., [w:] Statuta, s. 28; Statuta diocesana pro diocesi Luceoriensis $z 1519$ r., [w:] J. Sawicki, CP, t. 3: Synody diecezji łuckiej i ich statuty, Warszawa 1949, s. 88.

${ }^{28}$ Przykłady jak w przypisie wyżej. Odnotować jednak trzeba, iż w statutach synodu diecezjalnego włocławskiego biskupa Drzewickiego z 1516 r. wyjątkowo widnieje meretricia veste a nie meretricia facie, jak w przypadku innych statutów synodalnych, zob. [w:] Statuta, s. 28.

${ }^{29}$ Statuta synodi a. 1554 celebratae, CP, t. 8, s. 167.

${ }^{30}$ Constitutiones et decreta Synodi Dioecesanae Posnaniensis praesidente... Andrea de Szołdry Szołdrski... Episcopo Posnaniensi, Posnaniae 1642, k. F 4 r.

${ }^{31}$ Statuty Jana $z$ Książąt Litewskich $z 1528$ r., CP, t. 2, s. 120.

32 Jacobus Archiepiscopus Gneznensis a. 1285: [...] concubinas huiusmodi per dictos nuncios faciant captivari, [...] capte autem cum sua prole taliter acquisita ([...] konkubiny tego rodzaju mają być schwytane przez rzeczonych posłańców, [...] schwytane z potomstwem w ten sposób zrodzonym), [w:] A. Z. Helcel, SPPP, t. 1, Warszawa 1856, s. 384. Identyczną regulację zawierały Statuty kaliskie arcybiskupa Jarosława z 1357 r., [w:] Codex Diplomaticus Maioris Poloniae (dalej: Codex Diplomaticus), t. 3, Poznań 1879, s. 61.

${ }^{3}$ Statuta Thomae Strzępiński Episcopi...: [...] qui etiam ex tali concubinatu procreatos filios apud patres suos cohabitare non permittant ([...] nie pozwolą też, aby dzieci zrodzone $\mathrm{z}$ takiego konkubinatu mieszkały wraz ze swymi ojcami), SPPP, t. 4, s. 112; Acta et constitutiones synodi a Johanne V Turzone anno 1509 celebratae, CP, t. 10, s. 556.

${ }^{34} \mathrm{~W}$ pełnej treści przywołanego statutu: Clericus de proventibus anni gracie vel alias de rebus ecclesiae acquisitis concubinae suae vel filis ex fornicatione genitis quidquam penitus non relinquat, zabroniono duchownemu pozostawienia w spadku swojej konkubinie i dzieciom spłodzonym w rozpuście czegokolwiek z dóbr Kościoła, zob. Statuty synodalne wieluńsko-kaliskie Mikołaja Trąby..., s. 54. 
in concubinatu [...] permanent ${ }^{35}$, seque ab eorum consuetudine non seiunxerint ${ }^{36}$, si in eodem delicto [...] perseveraverint ${ }^{37}$, sin vero in tam profundum pelagus malorum inciderint ${ }^{38}$, czy in peccatis mortalibus continuo permanentes $[. . .]^{39}$. Ponadto źródła kościelne zawierały niezwykle szeroki wachlarz czasowników wskazujących, najogólniej mówiąc, na fakt stałego posiadania przez mężczyznę konkubiny. Najczęściej używanymi były: habere ${ }^{40}$ (mieć, posiadać), retine$r e^{41}$, detinere ${ }^{42}$ (trzymać) oraz fovere ${ }^{43}$ (utrzymywać, otaczać opieką). Rzadziej w omawianym kontekście pojawiały się takie, jak: tenere ${ }^{44}$ (zatrzymać kogoś przy sobie, pozostawać z kimś w związku), adiungere ${ }^{45}$ (wejść w związek z kimś) czy servare ${ }^{46}$ (utrzymywać). Niektóre ze stosowanych form podkreślały wyraźnie alimentacyjny aspekt relacji łączących mężczyznę z określoną kobietą. I tak na przykład w kodyfikacji płockiej biskupa Jakuba z lat 1398-1423 posłużono się czasownikiem nutrire ${ }^{47}$, którego podstawowe znaczenie to karmić, żywić ${ }^{48}$. Z kolei na synodzie diecezjalnym wrocławskim z 1580 r., za rządów biskupa Marcina Gerstmanna (1574-1585), w rozdziale traktującym o karach kościelnych nakładanych na wiernych świeckich dopuszczających się konkubinatu użyto czasownika alere ${ }^{49}$, tożsamego znaczeniowo z wyżej wspomnianymi czynnościami. Także biskup wrocławski Wacław w statutach synodalnych ogłoszonych w 1410 r. zakazywał duchownym utrzymywania konkubin i dostarczania im środków żywnościowych ${ }^{50}$. Odnotować także wypada formy pochodzące od

${ }^{35}$ Acta dioecesanae synodi Anno Domini MDLXXX, CP, t. 10, s. 572.

${ }^{36}$ Ibidem, s. 572; Synodus Varmiensis sub Simone Rudnicki a. 1610, [w:] Decretales, t. 3, s. 165.

${ }^{37}$ Statuta synodi A. 1641 celebratae, CP, t. 8, s. 279.

38 Constitutiones et decreta Synodi Dioecesanae Posnaniensis praesidente... Andrea de Szołdry Szołdrski... Episcopo Posnaniensi, Posnaniae 1642, k. F4 v.

${ }^{39}$ Statuta synodi A. 1415 celebratae, CP, t. 8, s. 137.

${ }^{40}$ Statuty kaliskie arcybiskupa Jarosława z 1357 r., [w:] Codex Diplomaticus, t. 3, s. 61; Statuta synodalia domini Petri episcopi Wratislaviensis, CP, t. 10, s. 471; Dekrety kardynała legata Mikołaja z Kuzy dla diecezji wrocławskiej z 1451 r., CP, t. 10, s. 488.

${ }^{41}$ Synodus Budensis anni 1279 Philippus Firmanus Episcopus Legatus, [w:] Antiquissimae, s. 80.

${ }^{42}$ Synodus Wratislaviensis a. 1266 Guido Cardinalis Legatus, [w:] Antiquissimae, s. 58; Constitutiones synodales Thomae episcopi Wratislaviensis anno 1279 promulgatae, CP, t. 10, s. 331; Akta synodów biskupa Wojciecha Baranowskiego z 1593 r., CP, t. 6, s. 342; Synodus Dioecesana Andrea Lipski Episcopi Wladislaviensis die 4 Maii Anno Domini 1628, [w:] Statuta, s. 187.

${ }^{43}$ Statuta Joannis IV Grot Episcopi..., SPPP, t. 4, s. 38; Kodyfikacja płocka biskupa Jakuba z 1398-1423 r., CP, t. 6, s. 231; Statuta synodalia domini Petri episcopi Wratislaviensis, CP, t. 10, s. 471.

${ }^{44}$ Statuta Joannis IV Grot Episcopi..., SPPP, t. 4, s. 38; Statuta Synodalia Nicolai Kurowski Episcopi Anno 1402, [w:] Statuta, s. 3; Ordinationes sub regimine Petri de Bnin Episcopi Anno 1487 editae, [w:] Statuta, s. 25.

${ }^{45}$ Statuty synodu płockiego bpa Andrzeja Chryzostoma Załuskiego z 1698 roku, Płock 1984, s. 109.

${ }^{46}$ Statuty Jana z Książąt Litewskich z 1528 r., CP, t. 2, s. 120.

${ }^{47}$ Kodyfikacja płocka biskupa Jakuba z 1398-1423 r., CP, t. 6, s. 231.

${ }^{48}$ J. Sondel, op. cit., s.v. nutrio, s. 669; M. Plezia, op. cit., t. 3, s.v. nutrio, s. 643.

${ }^{49}$ Było to dokładne powtórzenie dekretu soboru trydenckiego, sess. XXIV, cap. 8 de reform. matr.

${ }^{50}$ Constitutiones domini Wenceslai episcopi Wratislaviensis: concubinam [...] in domo sua vel aliena teneat et ei victualia ministret seu ministrari faciat, CP, t. 10, s. 385. 
czasownika ducere $^{51}$ (wziąć jako nałożnicę), jakie widnieją w statutach synodu łęczyckiego arcybiskupa Jakuba Świnki z roku 1285, czy kaliskiego arcybiskupa Jarosława ogłoszonych w 1357 r. Niekiedy przypadki utrzymywania konkubiny starano się oddać za pomocą wyrażeń opisowych, akcentując w nich jednocześnie fakt rozgłoszenia wśród społeczności wiernych informacji o tego rodzaju zabronionych praktykach. Tytułem przykładu wymienić można następujące: in sua procuratione publice detineat concubinam ${ }^{52}$ (swoim staraniem publicznie utrzymywał konkubinę), concubinam palam vel indubitanter teneat ${ }^{53}$ (jawnie i niewątpliwie trzymał konkubinę), indubitanter habere concubinam ${ }^{54}$ (niewątpliwie miał konkubinę) czy concubinam palam duxerit ${ }^{55}$ (jawnie wziął konkubinę). W przypadku ponownego przyjęcia konkubiny, po nałożonej uprzednio karze kanonicznej, stosowano czasowniki: reasumere ${ }^{56}$ resumere $^{57}$, receptare re $^{58}$, redire $^{59}$ oraz repetere ${ }^{60}$.

W treści norm synodalnych podkreślano, że w konkubinacie mogły trwać zarówno osoby stanu wolnego, jak i małżonkowie związani z jakąś osobą trzecią stanu wolnego lub zamężną. Wskazują na to wyrażenia: concubinarios, tam solutos, quam uxoratos ${ }^{61}$, [...] concubinarius, quicunque ille fuerit, sive solutus sive uxoratus aut aliqua soluta aut uxorata ${ }^{62}$ oraz mulieres sive coniugatae sive solutae, quae cum adulteris seu concubinariis publice vivunt ${ }^{63}$.

W świetle regulacji prawa kanonicznego dla zaistnienia konkubinatu nie miała znaczenia okoliczność czy mężczyzna utrzymywał niedozwolone stosunki z kobietą w swoim domu, czy też poza nim. Świadczy o tym niezbicie szereg

${ }^{51}$ Jacobus Archiepiscopus Gneznensis a. 1285: [...] concubinam palam duxerit, vel ductam non relin-querit [...], SPPP, t. 1, s. 384; identycznie Statuty kaliskie arcybiskupa Jarosława $z 1357$ r., [w:] Codex Diplomaticus, t. 3, s. 61.

${ }^{52}$ Kodyfikacja płocka biskupa Jakuba z lat 1398-1423 r., CP, t. 6, s. 231; Statuty synodalne wieluńsko-kaliskie Mikołaja Traby..., s. 48.

${ }^{53}$ Statuty kaliskie arcybiskupa Jarosława z 1357 r., [w:] Codex Diplomaticus, t. 3, s. 61.

${ }^{54}$ Statuty krakowsko-sandomierskie Jana Szafrańca z 1408 r., [w:] B. Ulanowski, Kilka uwag o statutach synodów dyjecezalnych krakowskich z XIV-go i XV stulecia, „Archiwum Komisji Historycznej Akademii Umiejętności”, t. 5, Kraków 1889, s. 23.

${ }_{55}$ Jacobus Archiepiscopis Gneznensis a. 1285, SPPP, t. 1, s. 384; Statuty kaliskie arcybiskupa Jarosława z 1357 r., [w:] Codex Diplomaticus, t. 3, s. 61.

${ }^{56}$ Statuta Synodalia Andreae episcopi Posnaniensis saeculo XV confecta, SPPP, t. 5, s. XIV; Uchwały synodu diecezjalnego gnieźnieńskiego z 1512 r., [w:] B. Ulanowski, Materyjały..., s. 355.

${ }^{57}$ Synodus Budensis anni 1279 Philippus Firmanus Episcopus Legatus, [w:] Antiquissimae, s. 80.

${ }^{58}$ Kodyfikacja płocka biskupa Jakuba z 1398-1423 r., CP, t. 6, s. 232.

${ }^{59}$ Statuta Thomae Strzępiński Episcopi..., SPPP, t. 4, s. 111; Statuta diocesana pro diocesi Luceoriensi $z 1519$ r., CP, t. 3, s. 88; Synodus Dioecesana Wladislaviae die 21 Sept. 1516 a. celebrata Matthias Drevicius..., [w:] Statuta, s. 28.

${ }^{60}$ Statuta synodalia domini Petri episcopi Wratislaviensis, CP, t. 10, s. 471.

${ }^{61}$ Synodus Varmiensis sub Simone Rudnicki a. 1610, [w:] Decretales, t. 3, s. 165; Acta dioecesanae synodi Anno Domini MDLXXX, CP, t. 10, s. 572.

${ }^{62}$ Synodus Kijoviensis sub Josephi Andrea Załuski a. 1762, [w:] Decretales, t. 3, s. 166.

${ }^{63}$ Acta dioecesanae synodi Anno Domini MDLXXX, CP, t. 10, s. 572. 
zwrotów, jakie mieściły analizowane teksty źródłowe. Do najczęściej stosowanych należały te $\mathrm{w}$ postaci: in domo vel extra domum ${ }^{64}$, in domibus propriis vel vicinis $^{65}$, in domo secum vel alibi in bonis ecclesie ${ }^{66}$, domi aut foris ${ }^{67}$, in domibus suis vel alias ${ }^{68}$. Nieco rzadziej odnaleźć można: quas secum in dote et domibus propriis aut alienis ${ }^{69}$, in hospitiis suis vel alibi ${ }^{70}$, intra domum, ita neque extra illam ${ }^{71}$, in domo propria vel alio loco ${ }^{72}$, in domibus suae habitationis retinere, vel alibi cum eis cohabitare praesumat ${ }^{73}$ oraz sub eodem tecto ${ }^{74}$.

\section{Terminologia określająca moralną i prawną ocenę pożycia w konkubinacie}

Konkubinat, stanowiący jaskrawe przeciwieństwo katolickiej koncepcji małżeństwa, postrzegany był na forum kościelnym przede wszystkim w kategoriach grzechu (peccatum ${ }^{75}$ ), przy czym często akcentowano fakt, że chodzi tu o ciężki (grave peccatum $)^{76}$, czy nawet najcięższy grzech (gravissimum peccatum) ${ }^{77}$, zwany także grzechem śmiertelnym (mortale peccatum $)^{78}$. Naturalną konsekwencją kwalifikowania pożycia w konkubinacie jako grzechu było stosowanie wobec wiernych świeckich i członków stanu duchownego terminów peccator ${ }^{79}$ (grzesznik) oraz scandalosus ${ }^{80}$ (gorszyciel). Jednak należy podkreślić, że prawodawcy synodalni szczególną uwagę przywiązywali do naprawy obyczajów duchowień-

${ }^{64}$ Statuta Synodalia Andreae episcopi Posnaniensis saeculo XV confecta, SPPP, t. 5, s. XIV; Statuta diocesana pro diocesi Luceoriensis z 1519 r., CP, t. 3, s. 88; Najdawniejsze statuty arcybiskupa Mikołaja Kurowskiego między 1407-1411 r., [w:] J. Sawicki, CP, t. 5: Synody archidiecezji gnieźnieńskiej i ich statuty, Warszawa 1950, s. 257.

${ }^{65}$ Kodyfikacja płocka biskupa Jakuba z 1398-1423 r., CP, t. 6, s. 231.

${ }^{66}$ Statuta Joannis IV Grot Episcopi..., SPPP, t. 4, s. 38.

${ }^{67}$ Statuty Jana $z$ Książą Litewskich $z 1528$ r., CP, t. 2, s. 120.

${ }^{68}$ Statuta Nankeri Episcopi Cracoviensis Ann. MCCCXX, SPPP, t. 4, s. 20.

${ }^{69}$ Statuta synodalia domini Petri episcopi Wratislaviensis, CP, t. 10, s. 471.

70 Synodus Wratislaviensis a. 1248 Jacobus Archidiaconus Leodiensis Legatus, [w:] Antiquissimae, s. 18 .

${ }^{71}$ Synodus Dioecesana sub... Mathia Eubieński..., [w:] Statuta, s. 237.

72 Synodus Siradiensis anni 1233 Fulco Archiepiscopus Gneznensis, [w:] Antiquissimae, s. 2.

${ }^{73}$ Synodus Budensis anni 1279 Philippus Firmanus Episcopus Legatus, [w:] Antiquissimae, s. 80.

${ }^{74}$ Synodus Dioecesana Wladislaviensis A. 1607 die 17 Septembris celebrata praesidente [...] Alberto Baranowski D.G. Episcopo Wladislaviensi et Pomeraniae, [w:] Statuta, s. 161.

${ }^{75}$ Constitutiones in concilio Posoniensi promulgatae a. 1309 Fratris Gentilis - cardinalis et Apostolicae Sedis in Ungaria et Polonia legati, SPPP, t. 1, Warszawa 1856, s. 394; Najdawniejsze statuty arcybiskupa Mikołaja Kurowskiego między 1407-1411 r., CP, t. 5, s. 258; Synodus Dioecesana Wladislaviae die 21 Sept. 1516 a. celebrata Matthias Drevicius..., [w:] Statuta, s. 28.

${ }^{76}$ Acta dioecesanae synodi Anno Domini MDLXXX, CP, t. 10, s. 572.

77 Ibidem, s. 572.

78 Tak np. Statuta synodi A. 1415 celebratae, CP, t. 8, s. 137.

${ }^{79}$ Constitutiones et decreta Synodi Dioecesanae Plocensis sub... Andrea Stanislao Kostka in Załuskie Załuski... Episcopo Plocensi Pultoviae Anno Dominii MDCCXXXIII celebratae, Varsaviae 1735, s. 22.

${ }^{80}$ Statuty synodalne wieluńsko-kaliskie Mikołaja Traby..., s. 49. 
stwa, zdecydowanie piętnując przypadki trwania przez nie w konkubinacie. I tak, legat papieski Jakub, późniejszy papież Urban IV (1261-1264) na synodzie odbytym w 1248 r. we Wrocławiu, jawne utrzymywanie konkubin przez duchownych określił mianem incorrigibile peccatum ${ }^{81}$, czyli grzechu niepoprawności kapłańskiej, ściągającego na winnych różnego rodzaju kary kościelne ${ }^{82}$.

W celu przedstawienia stanu moralnego, w jakim znajdowały się osoby żyjące w konkubinacie i skutków dla całej społeczności wiernych, posługiwano się również przenośnie terminami odnoszącymi się do szeroko rozumianego zdrowia fizycznego człowieka. Dlatego w regulacjach synodalnych odnaleźć można takie terminy, jak: morbus ${ }^{83}$ (choroba), corruptela ${ }^{84}$ (zepsucie), labes $^{85}$ (zaraza), foeditas ${ }^{86}$ (obrzydzenie), czy chyba najbardziej odrażający wyraz vomitus ${ }^{87}$, oznaczający wymiociny.

Charakterystyczne było to, że termin concubinatus niezwykle rzadko występował samodzielnie, bez towarzyszących mu określeń. Poprzedzano go najczęściej przymiotnikami mającymi wyraźnie negatywną ocenę. Należały do nich: turpis ${ }^{88}$, który w tłumaczeniu na język polski oznacza szkaradny, szpetny, nikczemny, haniebny, bezwstydny, nieprzyzwoity, wszeteczny czy lubieżny ${ }^{89}$, następnie sceleratus ${ }^{90}$, czyli przeklęty, występny, zgubny, straszny ${ }^{91}$ lub foedus ${ }^{92}$ rozumiany jako obrzydliwy, szkaradny, plugawy, sprośny, wstrętny, okropny

${ }^{81}$ Synodus Wratislaviensis a. 1248 Jacobus Archidiaconus Leodiensis Legatus, [w:] Antiquissimae, s. 17.

82 Szerzej na temat sankcji stosowanych wobec duchownych żyjących w konkubinacie zob. K. Szczygielski, Problematyka konkubinatu w uchwałach soborów powszechnych XII-XVI wieku, „Miscellanea Historico-Iuridica" 2006, t. 4, s. 47-53.

${ }^{83}$ Tak np. Kodyfikacja płocka biskupa Jakuba z 1398-1423 r., CP, t. 6, s. 232.

${ }^{84}$ Statuty krakowsko-sandomierskie Jana Szafrańca z 1408 r., [w:] B. Ulanowski, Kilka uwag..., s. 23.

${ }^{85}$ Synodus Provincialis sub Laurentio Gembicki a. 1621, [w:] Decretales, t. 2, Posnaniae 1882, s. 104.

${ }^{86}$ Statuta Synodalia domini Petri episcopi Wratislaviensis, CP, t. 10, s. 471.

${ }^{87}$ Cały odnośny fragment brzmiał następująco: Qui post dispensationem recidivo vomitu ad huiusmodi publicum concubinatum redierint (Ci zaś, którzy po przebaczeniu znowu powrócą do wymiotu takiego publicznego konkubinatu), zob. sobór bazylejski, sess. XX., Dokumenty Soborów Powszechnych, oprac. A. Baron. H. Pietras, t. 3, Kraków 2004, s. 352. Dekret soborowy powtarzają Statuta Thomae Strzępiński Episcopi..., SPPP, t. 4, s. 111. Warto odnotować, że w tekstach innych polskich synodów używano nieco innego zwrotu: [...] rediret ut canis ad vomitum [...] (wróci jak pies do wymiocin), zob. Statuta Synodalia Andreae episcopi Posnaniensis saeculo XV confecta, SPPP, t. 5, s. XIV; Statuta diocesana pro diocesi Luceoriensis z 1519 r., CP, t. 3, s. 88.

${ }^{88}$ Statuta synodi A. 1641 celebratae, CP, t. 8, s. 279.

${ }^{89}$ F. Bobrowski, op. cit., t. 2, s.v. turpis, s. 892; A. Jougan, op. cit., s.v. turpis, s. 704; J. Sondel, op. cit., s.v. turpis, s. 692; M. Plezia, op. cit., t. 5, s.v. turpis, s. 466.

${ }_{90}$ Zob. Statuty synodalne wieluńsko-kaliskie Mikołaja Trąby.., s. 48.

${ }^{91}$ F. Bobrowski, op. cit., t. 2, s.v. sceleratus, s. 639; A. Jougan, op. cit., s.v. sceleratus, s. 608; J. Sondel, op. cit., s.v. sceleratus, s. 863; M. Plezia, op. cit., t. 5, s.v. sceleratus, s. 54.

${ }_{92}^{2}$ Tak np. Statuta synodalia domini Petri episcopi Wratislaviensis, CP, t. 10, s. 471. 
lub ohydny ${ }^{93}$. W ten sposób chciano spotęgować niechęć czy nawet wstręt społeczności wiernych do tego rodzaju nieślubnych relacji. Z kolei na polu kościelnego prawa karnego pożycie w konkubinacie jawiło się jako naruszenie obowiązujących przepisów prawnych, stąd też obecność w źródłach takich terminów, jak: crimen $^{94}$, delictum ${ }^{95}$, vitium ${ }^{96}$, scelus ${ }^{97}$ czy też excessus $^{98}$ oznaczających przestępstwo, występek, wykroczenie bądź nadużycie. Były one następnie dookreślane poprzez dodanie przymiotników wyrażających jednoznacznie ujemną kwalifikację takiego postępowania. Wymienić tu można: pestiferum crimen ${ }^{99}$ (zgubne, szkodliwe przestępstwo), fornicationis crimen ${ }^{100}$ (przestępstwo rozpusty), car$n_{\text {nis }}$ vitium $^{101}$ (występek cielesny), detestabilis vitium ${ }^{102}$ (obrzydliwy występek). Zasiadający na stolicy gnieźnieńskiej arcybiskupi Jakub Świnka (1283-1314) i Jarosław Bogoria Skotnicki (1342-1376) przypominali duchownym pozostającym w publicznym konkubinacie, że popadają oni w przestępstwo świętokradztwa (sacrilegii crimen incurrant) ${ }^{103}$. Biskup krakowski Nanker w statutach z 1320 r. dążył do doszczętnego wykorzenienia wśród duchowieństwa latorośli zaraźliwego przestępstwa (De vinea domini labruscas huiusmodi contagiosi criminis [...] funditus eradicare volentes ${ }^{104}$. Podobnie artykułował swoje zamiary w XV w. biskup Maciej zwany Janiną, pragnąc radykalnie, skutecznie, na zawsze wykorzenić to godne potępienia przestępstwo ze względu na zbawienie dusz podległych mu wiernych (hoc crimen dampnabile pro salute nostrorum

${ }^{93}$ F. Bobrowski, op. cit., t. 1, s.v. foedus, s. 757; A. Jougan, op. cit., s.v. foedus, s. 265; J. Sondel, op. cit., s.v. foedus, s. 389; M. Plezia, op. cit., t. 2, s.v. foedus, s. 567.

${ }_{94}$ Tak Synodus Wratislaviensis a. 1266 Guido Cardinalis Legatus, [w:] Antiquissimae, s. 59; Constitutiones synodales Thomae episcopi Wratislaviensis anno 1279 promulgatae, CP, t. 10, s. 331; Statuta Thomae Strzępiński Episcopi..., SPPP, t. 4, s. 111; Acta dioecesanae synodi Anno Domini MDLXXX, CP, t. 10 , s. 573

95 Jacobus Archiepiscopus Gneznensis a. 1285, SPPP, t. 1, s. 385; Statuty kaliskie arcybiskupa Jarosława z 1357 r., [w:] Codex Diplomaticus, t. 3, s. 61; Dekrety kardynała legata Mikołaja z Kuzy dla diecezji wrocławskiej z 1451 r., CP, t. 10, s. 488.

96 Tak np. Kodyfikacja płocka biskupa Jakuba z 1398-1423 r., CP, t. 6, s. 232.

${ }^{97}$ Constitutiones et decreta Synodi Dioecesanae Posnaniensis praesidente... Andrea de Szołdry Szołdrski... Episcopo Posnaniensi, Posnaniae 1642, k. F4 r.

98 Zob. Statuty kaliskie arcybiskupa Jarosława z 1357 r., [w:] Codex Diplomaticus, t. 3, s. 61; Kodyfikacja płocka biskupa Jakuba z 1398-1423 r., CP, t. 6, s. 232.

${ }_{99}$ Tak np. Statuty krakowsko-sandomierskie Jana Szafrańca z 1408 r., [w:] B. Ulanowski, Kilka uwag..., s. 23.

100 Statuta Thomae Strzępiński Episcopi..., SPPP, t. 4, s. 112.

101 Tak np. Statuta Nankeri Episcopi Cracoviensis Ann. MCCCXX, SPPP, t. 4, s. 20.

102 Constitutiones et decreta Synodi Dioecesanae Plocensis sub... Andrea Stanislao Kostka in Załuskie Załuski... Episcopo Plocensi Pultoviae Anno Dominii MDCCXXXIII celebratae, Varsaviae 1735, s. 22.

103 Jacobus Archiepiscopus Gneznensis a. 1285, SPPP, t. 1, s. 385; Statuty kaliskie arcybiskupa Jarosława z 1357 r., [w:] Codex Diplomaticus, t. 3, s. 61.

104 Zob. Statuta Nankeri Episcopi Cracoviensis Ann. MCCCXX, SPPP, t. 4, s. 20. 
subditorum radicatus extirpare cupientes [...] in perpetuum valituro $)^{105} . \mathrm{Z}$ kolei w statutach synodu płockiego, który odbył się pod przewodnictwem biskupa Andrzeja Chryzostoma Załuskiego w 1698 r., pozostawanie w konkubinacie przez osoby duchowne określone zostało jako crimen qualificatum, czyli przestępstwo kwalifikowane rodzące zgrozę i szczególne zgorszenie (horrorem et summum scandalum pariunt ${ }^{106}$. W aktach synodów biskupa Wojciecha Baranowskiego z 1593 r. publicznych konkubentów nazwano facinorosi homines ${ }^{107}$, czyli osobami żyjącymi występnie.

Stan uporczywego trwania w konkubinacie starano się oddać za pomocą różnych wyrażeń opisowych. Ogromna większość z nich odnosiła się do duchownych. Tytułem przykładu przywołać należy następujące: male et scandalose viventes ${ }^{108}$ (żyjący niegodziwie i w zgorszeniu), communi fidelium omnium offensione summoque clericalis militiae dedecore testatur ${ }^{109}$ (przynoszący zgorszenie całej wspólnocie wiernych i największe oszpecenie stanu duchownego), continuo peccatorum sordibus fedari ${ }^{110}$ (pozostający w brudach szkaradnego grzechu) czy [...] que a nonnullis, in ipsorum et laycorum scandalum et animarum periculum dampnabiliter violantur ${ }^{111}$ (przez niektórych (duchownych) są szkodliwie łamane (normy obwarowane sankcjami) ku zgorszeniu ich samych, jak i świeckich i niebezpieczeństwu zbawienia dusz). Niezwykle barwnie opisywał zjawisko konkubinatu przywołany wyżej biskup Nanker, stwierdzając, że ten występek cielesny swoim zgubnym wpływem zaraził już bardzo wielu, rozpuszczając szpetne macki po granicach całej naszej diecezji (quo quidem carnis vitium [...] suo tamen contagio iam plurimos maculavit, propagines sue turpitudinis per omnes nostre diocesis fines dilatando $)^{112}$.

Warto odnotować również, iż wielokrotnie na synodach zwracano uwagę na fakt rozgłoszenia informacji o pożyciu w konkubinacie, co wpływało na procedurę wymiaru kar stosowaną przez odpowiednie władze kościelne. Stąd nie

105 Statuta synodi A. 1415 celebratae, CP, t. 8, s. 137.

106 Statuty synodu płockiego bpa Andrzeja Chryzostoma Załuskiego..., wyd. W. Góralski, s. 110.

107 Akta synodów biskupa Wojciecha Baranowskiego z 1593 r., CP, t. 6, s. 328; Constitutiones et decreta Synodi Dioecesanae Plocensis sub... Andrea Stanislao Kostka in Załuskie Załuski... Episcopo Plocensi Pultoviae Anno Dominii MDCCXXXIII celebratae, Varsaviae 1735, s. 21.

108 J. Sawicki, CP, t. 1: Statuty synodalne krakowskie biskupa Jana Konarskiego z 1509 r., Lublin 1961, s. 49.

109 Statuty synodu płockiego bpa Andrzeja Chryzostoma Załuskiego..., wyd. W. Góralski, s. 110; Acta dioecesanae synodi Anno Domini MDLXXX, CP, t. 10, s. 573.

110 Constitutiones in concilio Posoniensi promulgatae a. 1309, SPPP, t. 1, s. 394.

111 Statuta Joannis IV Grot Episcopi..., SPPP, t. 4, s. 38.

112 Statuta Nankeri Episcopi Cracoviensis Ann. MCCCXX, SPPP, t. 4, s. 20. 
budzi zdziwienia częsta obecność $\mathrm{w}$ ich statutach przymiotników: publicus ${ }^{113}$ (publiczny), manifestus ${ }^{114}$ (jawny) i notorius ${ }^{115}$ (notoryczny).

Najważniejszym z punktu widzenia Kościoła katolickiego wyzwaniem związanym ze zjawiskiem konkubinatu było doprowadzenie do zerwania przez wiernych ze stanem grzesznego pożycia. Przejawiana na tym polu troska władz kościelnych sprawiła, że zachowane źródła obfitują w czasowniki, które wyrażały intencję Kościoła, by konkubenci zaprzestali trwania w niedozwolonym związku. Gamę czasowników, do których uciekano się najczęściej otwierają: dimitte$r e^{116}$ (odesłać, oddalić od siebie), reicere ${ }^{117}$ (porzucić, pozbyć się), relinquere ${ }^{118}$ (zostawić, opuścić), removere ${ }^{119}$ (usunąć, wypędzić), seiungere ${ }^{120}$ (rozdzielić, odłączyć), eicere ${ }^{121}$ (wygnać $\mathrm{z}$ domu, przepędzić) oraz desistere ${ }^{122}$ (zaniechać, odstąpić od czegoś). Dużo rzadziej odnotować można czasownik separare ${ }^{123}$ (oddzielić, odosobnić) użyty przez kardynała legata Gwidona na synodzie z 1267 roku, następnie abstinere ${ }^{124}$ (powstrzymywać się od czegoś), jaki widnieje między innymi w treści statutów przemyskich biskupa Piotra Gembickiego z roku 1641, czy też zamieszczony w aktach synodu płockiego biskupa Andrzeja Kostki Załuskiego z 1733 r. czasownik expedire ${ }^{125}$, który tłumaczyć należy jako uwolnie-

113 Statuta Thomae Strzępiński Episcopi..., SPPP, t. 4, s. 111; Acta et constitutiones synodi a Johanne $V$ Turzone anno 1509 celebratae, CP, t. 10, s. 555; Uchwaly synodu prowincjonalnego piotrkowskiego $z 1542$ r., [w:] B. Ulanowski, Materyjały..., s. 398.

114 Statuta Synodalia Andreae episcopi Posnaniensis saeculo XV confecta, SPPP, t. 5, s. XIV; Synodus Provincialis sub Laurentio Gembicki a. 1621, [w:] Decretales, t. 2, s. 104.

115 Najdawniejsze statuty arcybiskupa Mikołaja Kurowskiego między 1407-1411 r., CP, t. 5, s. 257; Statuta diocesani pro diocesi Luceoriensis z 1519 r., CP, t. 3, s. 88.

116 Statuta synodalia Nicolai Kurowski Episcopi Anno 1402, [w:] Statuta, s. 3; Statuta Synodalia Andreae episcopi Posnaniensis saeculo XV confecta, SPPP, t. 5, s. XIV; Statuta synodi A. 1415 celebratae, CP, t. 8, s. 13; Statuta Thomae Strzępiński Episcopi..., SPPP, t. 4, s. 111.

117 Statuta synodalia domini Petri episcopi Wratislaviensis, CP, t. 10, s. 471.

118 Jacobus Archiepiscopus Gneznensis a. 1285, SPPP, t. 1, s. 384; Statuty kaliskie arcybiskupa Jarosława z 1357 r., [w:] Codex Diplomaticus, t. 3, s. 61.

119 Synodus Wratislaviensis a. 1248 Jacobus Archidiaconus Leodiensis Legatus, [w:] Antiquissimae, s. 18.

120 Synodus Varmiensis sub Simone Rudnicki a. 1610, [w:] Decretales, t. 3, s. 165; Constitutiones et decreta Synodi Dioecesanae Plocensis sub... Andrea Stanislao in Załuskie Załuski... Episcopo Plocensi Pultoviae Anno Dominii MDCXXXIII celebratae, Varsaviae 1735, s. 22.

121 Synodus Budensis anni 1279 Philippus Firmanus Episcopus Legatus, [w:] Antiquissimae, s. 80; Synodus Varmiensis sub Simone Rudnicki a. 1610, [w:] Decretales, t. 3, s. 165.

122 Statuty synodalne wieluńsko-kaliskie Mikołaja Trąby..., s. 48; Statuta synodalia domini Petri episcopi Wratislaviensis, CP, t. 10, s. 471.

${ }_{123}$ Synodus Wratislaviensis a. 1266 Guido Cardinalis Legatus, [w:] Antiquissimae, s. 59.

124 Statuta synodi A. 1641 celebratae: [...] qui a suis superioribus moniti a concubinatus peccato non abstinerent, CP, t. 8, s. 279; Dekrety kardynała legata Mikołaja z Kuzy dla diecezji wrocławskiej z 1451 r., CP, t. 10, s. 487; Statuta Thomae Strzępiński Episcopi..., SPPP, t. 4, s. 111; Statuty synodu płockiego bpa Andrzeja Chryzostoma Załuskiego..., wyd. W. Góralski, s. 106.

${ }_{125}$ Constitutiones et Decreta Synodi Dioecesanae Plocensis sub... Andrea Stanislao Kostka in Załuskie Załuski... Episcopo Plocensi Pultoviae MDCCXXXIII celebratae, Varsaviae 1735, s. 22. 
nie się z sideł konkubinatu. Biskup wrocławski Piotr Nowak, wzywając w 1448 roku wszystkich duchownych podległej mu diecezji do zaprzestania zażyłych relacji z konkubinami, posłużył się formą czasownika purgare ${ }^{126}$ (oczyścić). Z kolei kardynał legat Mikołaj z Kuzy na synodzie w Minden w 1451 r., w rozdziale IX poświęconym walce $\mathrm{z}$ konkubinatem duchownych, użył czasownika eliminare $^{127}$ (zniweczyć). Synod łęczycki Jakuba Świnki z 1285 r. wzmiankował natomiast o uwolnieniu się (liberare) konkubentów od hańby i zgorszenia ${ }^{128}$. Jeszcze w inny sposób troskę o poprawę życia i obyczajów duchowieństwa wyraził biskup Hieronim Rozrażewski, który w roku 1585 zachęcał do wystrzegania się (fugere) konkubinatu ${ }^{129}$. Poznański prawodawca synodalny natomiast, biskup Andrzej Szołdrski, przypominał wiernym o karach grożących tym, którzy nie zerwą (abdicare) ${ }^{130}$ tego grzesznego związku.

\section{Wnioski}

Przeprowadzona analiza średniowiecznych i przedrozbiorowych uchwał synodów prowincjonalnych i diecezjalnych pozwala stwierdzić, iż zachowało się w nich stosunkowo dużo fragmentów odnoszących się do problematyki konkubinatu. Dowodzą one nieprzerwanej obecności tego pozamałżeńskiego związku w życiu społecznym Kościoła katolickiego. Świadczą także o tym, że kościoły partykularne w Polsce zwalczały to zjawisko za pomocą stanowionych norm prawnych. Użyta zaś w nich łacińska terminologia wyraża jednoznacznie negatywne stanowisko wspólnoty Kościoła do konkubinatu.

Prześledzenie stosowanej w polskim ustawodawstwie synodalnym XII-XVIII w. terminologii traktującej o konkubinacie prowadzi do stwierdzenia, że niektóre z określeń pojawiały się stale na przestrzeni kilku stuleci, tworząc tym samym specyficzny język kościelnych norm prawnych. Warto podkreślić, że przywołane terminy w ogromnej mierze odnosiły się do duchownych pozostających in statu concubinatu. Fakt ten pozwala wyciągnąć wniosek, że zwierzchnicy kościołów partykularnych zwracali szczególną uwagę na przestrzeganie karności kapłańskiej. Analizowane regulacje ukazują ponadto, że Kościół ka-

126 Statuta synodalia domini Petri episcopi Wratislaviensis: [...] a concubinatus scelerata feditate purgati [...], CP, t. 10, s. 471.

${ }^{127}$ Dekrety kardynała legata Mikołaja z Kuzy dla diecezji wrocławskiej z 1451 r., [...] concubinatus feditatem de domo Domini eliminare [...], CP, t. 10, s. 487.

128 Synodus Wratislaviensis a. 1248 Jacobus Archidiaconus Leodiensis Legatus, [w:] Antiquissimae, s. 19.

129 Acta synodi ruralium decanatum Pomeraniae ex mandato [...] Hieronimi ep. Wladislavien. et Pomeraniae [...] anno 1585 Gedani celebratae: [...] et maxime foedissimi ac turpissimi concubinatus fuga, [w:] Statuta, s. 92.

130 Constitutiones et decreta Synodi Dioecesanae Posnaniensis praesidente... Andrea de Szołdry Szołdrski... Episcopo Posnaniensi, Posnaniae 1642, k. G1 r. 
tolicki w Polsce oczekiwał w pierwszym rzędzie od członków stanu duchownego świadectw wiary i chrześcijańskich reguł moralnego postępowania. Tym też należy tłumaczyć występowanie w aktach większości synodów tytułów: De vita et honestate clericorum, De cohabitatione clericorum et mulierum, De vita inhonesta clerni, De concubinis clericorum, czy De concubinatu clericorum, w których zamieszczano stosowne przepisy dotyczące tej formy faktycznego pożycia. Dużo rzadziej natomiast można w nich spotkać odrębne fragmenty poświęcone walce Kościoła z konkubinatem wiernych świeckich.

Przedstawiona terminologia odznacza się zabarwieniem pejoratywnym. Bez wątpienia odzwierciedla ona nieprzychylny stosunek Kościoła do konkubinatu oraz osób w nim żyjących. Nadrzędnym celem, jakim kierowali się prawodawcy synodalni, było uświadomienie całej wspólnocie wiernych ogromnej szkodliwości pozostawania w tym grzesznym związku w sferze religijnej, moralnej i społecznej. Abominacja ze strony władz kościelnych nie może specjalnie dziwić, stąd też statuty synodalne zawierały wiele kanonicznych sankcji dyscyplinarnych i karnych.

Prawodawcy partykularni, ogłaszając uchwały synodalne, czerpali w szerokim zakresie z terminologii, jaką posługiwano się w prawie powszechnym. Pośrednio świadczy ona o tym, że w badanym okresie rozwoju prawa synodalnego w Polsce nie stwierdza się radykalnej zmiany w kwestii podejścia do problematyki konkubinatu. Warto zaznaczyć jednak, iż w treści norm polskiego ustawodawstwa kościelnego odnaleźć można również terminy niespotykane in iure canonico universali, co świadczy o osobliwości rodzimych regulacji prawnych. Ich obecność przyczyniła się do poszerzenia wachlarza terminologii odnoszącej się do konkubinatu, ale ani nie zradykalizowały one jej wymowy, ani też jej nie osłabiły. 